\title{
The symbiotic hesionid Parasyllidea humesi Pettibone, 1961 (Annelida: Polychaeta) hosted by Scrobicularia plana (da Costa, 1778) (Mollusca: Bivalvia: Semelidade) in European waters
}

\author{
Daniel Martin $\cdot$ José A. Cuesta $\cdot$ Pilar Drake $\cdot$ João Gil $\cdot$ Arne Nygren $\cdot$ Fredrik \\ Pleijel \\ D. Martin $(\equiv) \cdot J$. Gil
}

Centre d'Estudis Avançats de Blanes (CEAB-CSIC) - Carrer d'Accés a la Cala Sant Francesc 14, 17300 Blanes (Girona), Catalunya (Spain).

E-mail: dani@ceab.csic.es Tel: +34 972336101. Fax: +34 972337806

J. A. Cuesta $\cdot$ P. Drake

Instituto de Ciencias Marinas de Andalucía (ICMAN-CSIC), Avenida República Saharaui 2, Puerto Real 11519, Cádiz, Spain.

F. Pleijel

Department of Biological and Environmental Sciences - Tjärnö, University of GothenburgSE 45296 Strömstad, Sweden.

\begin{abstract}
A. Nygren
University of Gothenburg, Department of Zoology, Systematics and Biodiversity, Box 463, SE-405 30

Göteborg, Sweden
\end{abstract}

\begin{abstract}
Heretofore, the hesionid polychaete Parasyllidea humesi was only known from its original description, living in association with the bivalve Tellina nymphalis in mangrove swamps north of Pointe-Noire (Republic of Congo, West Africa). The discovery of a stable population in Río San Pedro (Gulf of Cádiz, southern Atlantic coast of Iberian Peninsula) thus represents the second report for this species worldwide, and the first for European waters. Furthermore, the new population is associated with another bivalve, Scrobicularia plana. The host-symbiont relationship is characterized by a high host-specificity (the symbiont was absent from Ruditapes decussatus and
\end{abstract}


Cerastoderma glaucum collected in the same habitat and location), regular distribution (one, exceptionally two symbionts per host and then being male and female), and prevalence ranging from $0.22 \%$ (in Caño Sancti Petri) to $4.74 \%$ (Río San Pedro). The symbionts seem to affect the metabolism of their hosts and, thus, their normal growth, so this association may tentatively be considered as close to parasitism. Parasyllidea humesi seems to be restricted to salt marsh areas with stable marine salinities all over the year. As there is no evidence that the presence of P. humesi in the Gulf of Cádiz results from an introduction, we strongly suggest that it may be better considered as native to the region, with our finding representing the northernmost known geographical limit of its distribution.

Keywords: Hesionidae; Symbiosis; Bivalvia; NE Atlantic; Iberian Peninsula.

Running head: New symbiotic hesionid for the European Atlantic coasts

\section{Introduction}

The Hesionidae (Annelida: Polychaeta) are relatively small polychaetes usually less than $50 \mathrm{~mm}$ long, which are most often considered as active carnivores. They occur widely from both hard and soft subtidal habitats to the deep sea, where they are frequent but rarely dominant numerically, and also on intertidal habitats, most often as interstitial forms.

Like many other polychaete families, some species have developed symbiotic modes of life. Among them, Parasyllidea humesi Pettibone, 1961 was originally described as new genus and species from specimens living inside the mantle cavity of the bivalve Tellina nymphalis Lamarck, 1818 occurring in shallow waters in the vicinity of mangrove swamps at Luango, North to Pointe Noire, Middle Congo (Republic of Congo, West Africa) (Pettibone 1961). Since then, the species has never been reported again. Only two species have been later included within the genus: P. australiensis Hartmann-Schröder, 1980, based in a single record (Hartmann-Schröder 1980) and $P$. blacki (Knox 1960), an eyeless species from deep water originally described as 
Nereimyra blacki and later transferred to Parasyllidea by Pleijel (1998). None of them have been reported as symbionts.

During the study of the association between the pinnotherid crab Afropinnotheres monodi Manning, 1993, and the peppery furrow shell Scrobicularia plana (Da Costa, 1778), the grooved carpet shell Ruditapes decussatus (Linnaeus, 1767), and the lagoon cockle Cerastoderma glaucum (Bruguière, 1789) in the Gulf of Cádiz (Atlantic coast of southern Iberian Peninsula) (Subida et al. 2011), a stable population of Parasyllidea humesi was discovered living also in association with $S$. plana.

In this article, we report this finding, the second one for P. humesi worldwide, and the first for European waters. The characteristics of the association with the host bivalve, the second known for the species, are also described in terms of infestation rates, host/symbiont size relationships, and type of association.

\section{Material and methods}

Specimens of the host bivalve Scrobicularia plana were collected in February 2009 by hand digging at low tide in Río San Pedro and Caño Sancti Petri (Gulf of Cádiz, southern Atlantic coast of the Iberian Peninsula), as well as in other estuaries: Guadalquivir, Salado, Barbate, and Palmones (in Spain) and Ria Formosa (in Portugal) (Fig. 1). Additional specimens were collected in March, April, July, and August 2011 at Río San Pedro to confirm the presence of the species and to obtain enough material for a more detailed study of the association. Once collected, the bivalves were kept alive and transported to the laboratory, where they were counted, measured (length, width and height, in $\mathrm{mm}$ ), opened to check for the presence of the symbiont, and weighed (as dry weight: $80^{\circ} \mathrm{C}, 48 \mathrm{~h}$, without shell).

All obtained worms were counted, relaxed in isotonic magnesium chloride $(7.2 \mathrm{~g}$ $\mathrm{MgCl}_{2} \cdot 6 \mathrm{H}_{2} \mathrm{O}$ in $100 \mathrm{ml}$ of distilled water) and preserved in different preservatives for further studies (i.e., 95\% alcohol, in 4\% seawater/formalin solution and in a filtered seawater/osmium tetroxide solution). Prior to preservation, some selected worms were photographed in detail with a Canon EOS 5D Mark II, equipped with Canon MPE65/2.8 1-5x macro lens. As the worms may be easily damaged during handling, the relationships width/length and width/number of setigers were estimated to allow further comparisons between the hosts and their respective symbionts. Twenty entire worms 
were selected to estimate the width (at the tenth setiger, parapodia included, in mm) vs. length (in $\mathrm{mm}$ ) and number of segments relationships.

The worm/host size relationships were assessed by linear regression. The relationships between shell width, length, height, and biomass in infested and noninfested hosts were assessed using regression and covariance (ANCOVA) analyses. The corresponding relationships between width, length, and height were based on a subset of Scrobicularia plana specimens collected in June and July 2011 (72 specimens), while those between length and height were assessed later based on a different subset collected in July and August 2011 (41 specimens). All these analyses were carried out by means of the software XLSTAT version 2008.4.02, Copyright Addinsoft 1995-2008.

DNA was extracted using DNAeasy Tissue Kit (Qiagen) following the protocol supplied by the manufacturer. We used the primers $16 \mathrm{SarL}$ and $16 \mathrm{SbrH}$ for $16 \mathrm{~S}$ rDNA (Palumbi 1996). PCR mixtures contained $21 \mu 1 \mathrm{ddH}_{2} 0,1 \mu \mathrm{l}$ of each primer $(10 \mu \mathrm{M}), 2 \mu \mathrm{l}$ of DNA template, and puReTaq Ready-To-Go PCR beads (Amersham Biosciences).

The temperature profile was as follows: $96^{\circ} \mathrm{C} / 240 \mathrm{~s}-\left(94^{\circ} \mathrm{C} / 30 \mathrm{~s}-48-58^{\circ} \mathrm{C} / 30 \mathrm{~s}-\right.$ $72^{\circ} \mathrm{C} / 60 \mathrm{~s}$ ) $* 45$ cycles $-72^{\circ} \mathrm{C} / 480$ s. PCR products were purified with a $5 \mu$ l mixture of exonuclease I and FastAP thermosensitive alkaline phosphatase (Fermentas) (Werle et al. 1994). Sequencing was performed at Macrogen Inc. facilities (Seoul, Korea). Overlapping sequence fragments were merged into consensus sequences using Geneious 5.1.7 (Drummond et al. 2010).

The obtained 16S rDNA sequence and a voucher paragenophore (Pleijel et al. 2008) have been deposited in the GenBank and the "Museo Nacional de Ciencias Naturales" (MNCM) of Madrid, Spain, respectively.

\section{Results}

The Parasyllidea humesi specimens from the Gulf of Cádiz are relatively large hesionids, measuring around $30 \mathrm{~mm}$ in length for about 70 setigers (Figs. 2a, b). The species is characterized by having a prostomium with two lateral antennae, one minute median antenna (which seems to be lacking in some specimens), a clearly marked median antennal furrow (present in all specimens, independently of the presence of the median antenna), and two biarticulate palps. The species has six pairs of tentacular cirri (three pairs on each side), sub-biramous parapodia, and indistinct notopodia, 
represented by one acicula inside the elongate cirrophores of the dorsal cirri, and lacking capillary notosetae. Neurosetae are present from segment 4 . The neuropodia are conical, without extra lobes, and have compound heterogomph neurosetae with blades of varying length. The proboscis is unarmed and without papillae, and shows a ring of fine cilia around the opening. These characters placed the genus within the Ophiodrominae clade, as previously reported by Ruta et al. (2007). Accordingly, the best hit from a blast search of the $16 \mathrm{~S}$ rDNA sequence of P. humesi (GenBank accession no. JQ691830, MNCM 16.01/14309) is Ophiodromus pallidus (Claparède, 1864) (GenBank accession no. DQ442579) with a 76.9\% identity for the entire sequence length.

With the exception of a single specimen collected in Caño Sancti Petri from 461 Scrobicularia plana specimens, all P. humesi were found in Río San Pedro, and always in association with the same host species, S. plana (10 specimens from 269 clams in February 2009, 17/1065, 26/548, 11/339 and 10/378 in March, April, July, and August 2011, respectively). The corresponding prevalence was 0.22 in Caño Sancti Petri and $3.80,2.60,4.74,3.2$, and 2.6 in the Río San Pedro surveys, respectively. Neither Ruditapes decussatus $(\mathrm{n}=185)$ nor Cerastoderma glaucum $(\mathrm{n}=627)$ from Caño Sancti Petri, nor S. plana from the Guadalquivir $(\mathrm{n}=308)$, Salado $(\mathrm{n}=24)$, Barbate $(\mathrm{n}=717)$, Palmones $(n=125)$ and Ria Formosa $(n=139)$ estuaries hosted the symbiotic hesionid. In turn, the intensity of the infestation was always a single worm per host, except for a single case in June 2011, where two worms (one male and one female) co-inhabited the same $S$. plana specimen.

There were positive relationships between width (W) and length (L) of the worms, with higher significance when expressed in mm (Fig. 3a) rather than in the number of setigers (Fig. 3b):

$$
\begin{aligned}
& -\mathrm{L}(\text { in } \mathrm{mm})=-8.70981+13.8992 * \mathrm{~W}\left(\mathrm{t}=13.481, \mathrm{R}^{2}=0.910, \mathrm{p}<0.0001\right) \\
& -\mathrm{L}(\text { num. set. })=21.19995+17.12758 * \mathrm{~W}\left(\mathrm{t}=4.976, \mathrm{R}^{2}=0.579, \mathrm{p}<0.0001\right)
\end{aligned}
$$

The worms were located in the mantle cavity of the hosts, always in specimens measuring more than $20 \mathrm{~mm}$ in length, and were more frequent in intermediate-sized shells, i.e., from $>26 \mathrm{~cm}$ to about $36 \mathrm{~cm}$ long, which, in turn, were the most frequent shell lengths (Fig. 4a). As the symbionts were absent from the smallest hosts, there was a non-significant relationship (i.e., $\mathrm{R}^{2}=0.021$ ) between worm and shell lengths (Fig. 4b). 
The relationships of shell length vs. width, height and biomass were always significant, independently of the fact that $S$. plana shells were infested or not (Figs. 5a$5 c)$ :

- Length (L) vs. Width (W). Non-infested: $\mathrm{W}=0.7579 \mathrm{~L}-0.1622\left(\mathrm{R}^{2}=0.927\right.$, $\mathrm{t}=20.705, \mathrm{p}<0.0001)$; infested: $\mathrm{W}=0.7428 \mathrm{~L}-0.46\left(\mathrm{R}^{2}=0.949, \mathrm{t}=25.128, \mathrm{p}<\right.$ $0.0001)$

- Length (L) vs. Height (H). Non-infested: $H=0.3134 \mathrm{~L}-0.4281\left(\mathrm{R}^{2}=0.910, \mathrm{t}=\right.$ 13.826, $\mathrm{p}<0.0001)$; infested: $\mathrm{H}=0.3277 \mathrm{~L}-0.9462\left(\mathrm{R}^{2}=0.886, \mathrm{t}=11.814, \mathrm{p}<\right.$ $0.0001)$.

- Length (L) vs. Biomass (B). Non-infested: $B=0.0126 \mathrm{~L}-0.2433\left(\mathrm{R}^{2}=0.645\right.$, $\mathrm{t}=7.857, \mathrm{p}<0.0001)$. Infested: $\mathrm{B}=0.0095 \mathrm{~L}-0.1862\left(\mathrm{R}^{2}=0.616, \mathrm{t}=7.3869, \mathrm{p}<\right.$ $0.0001)$.

When comparing $\mathrm{L}$ vs. $\mathrm{W}$ and $\mathrm{L}$ vs. $\mathrm{H}$, there were non-significant differences between infested and non-infested $S$. plana shells (ANCOVA, $F=0.8434, p=0.362$ and $\mathrm{F}=0.2142, \mathrm{p}=0.646$, respectively) (Figs. 5a, 5b). Conversely, the infested shells had significantly lower biomasses for the same length than non-infested ones $($ ANCOVA $F=12.7461, \mathrm{p}<0.001)$ (Fig. 5c).

\section{Discussion}

The presence of Parasyllidea humesi in the Bay of Cádiz represents the second report of the species worldwide, and the first one in European waters. A stable European population of $P$. humesi was found only in Río San Pedro, an estuary characterized by having stable salinities of around 37.5\% on average during the whole year (ranging from 31 to $40 \%$, depending on the season) but, particularly, by lacking the strong fluctuations in the water salinity that typically occur in the remaining surveyed estuaries during rainfall periods. These estuaries often show fluctuations of more than $10 \%$ in a single rainfall episode (Subida et al. 2011). Accordingly, the presence of P. humesi seems to be restricted to salt marsh areas with stable marine salinities all year round. The same occurs with the pea-crab Afropinnotheres monodi found in the same habitat and inside the same host species (but never sharing the same clam), whose distribution also includes the Atlantic coasts of West Africa. Additionally, the dispersal of the species eastwards from the Bay of Cádiz may be limited by the ocean circulation from 
the African shelf towards the Gulf of Cádiz (Hagen 2001), as also reported for $A$. monodi (Subida et al. 2011). In turn, the coastal counter-current flowing westwards along the Gulf of Cádiz coast may form a cyclonic cell in its eastern part. Under certain conditions, this cell may reach the western region of the Gulf, and then progress towards the north under the influence of the Iberian Poleward Current (or Portugal Coastal Counter-current), which flows mostly in fall, winter, and beginning of spring (García-Lafuente et al. 2006). This environmental pattern allows us to postulate that the finding of $P$. humesi in the Gulf of Cádiz may be found in more northern areas. However, our finding currently represents the northern known limit for its distribution, and the species may certainly be native of the Gulf. In turn, the amount of Scrobicularia plana has not been examined in other Spanish regions often enough to fully discard the presence of the symbiont (e.g., less that 30 in Salado Estuary or less that 130 in Palmones Estuary), and the same occurs for the Portuguese coasts and the single surveyed estuary checked, Ria Formosa (i.e., about 140 bivalves). Moreover, in this estuary, the environmental conditions are adequate to allow the presence of the symbiont. Also, the fact that its presence may also be the result of a punctual and relatively recent introduction cannot be discarded, despite that there are no data supporting such a possibility. As the species has only been found twice, none of these hypotheses can be supported over the other, although we still consider the former as more reliable and parsimonious than the latter.

The original population of $P$. humesi from Congo was reported by Pettibone (1961) as living in association with Tellina nymphalis, a species that seems to have been cited mainly from the Western coasts of Africa. Tellina nymphalis was briefly and vaguely described by Lamarck (1818: 533), without supporting drawings or indication of type locality or habitat, and the name has been posteriorly applied, quite probably wrongly, to materials collected at estuarine shallow water habitats of Western Africa, which may belong to other species of Bivalvia. The current state of T. nymphalis is not clear, and the species is not cited in main recent works on the Mollusca from West Africa (e.g. Ardovini and Cossignani 2004) nor included (either as valid or synonymized) in WoRMS (Gofas 2011), so it may be an indeterminable or invalid species. In turn, the sparse graphic information found on T. nymphalis from West Africa, such as in the Natural History Museum of Rotterdam, catalogue no. NMR993000018393, http://nlbif.eti.uva.nl/nmr/detail.php?taal=uk\&naam, or in Nicklès (1950, fig. 432) shows a species closely resembling the genus Macoma, such as M. cf. 
innominata sensu Ardovini and Cossignani (2004), so a misidentification of the original host cannot be fully discarded.

In the Gulf of Cádiz, the association of $P$. humesi with $S$. plana appears as highly specific. Neither Ruditapes decussatus nor Cerastoderma glaucum, very abundant at the same location, hosted the polychaete. Also, there are no previous records of $P$. humesi (or a similar hesionid that could be misidentified by a non-specialist) as free-living, nor in the studied areas (Carvalho et al. 2011; Arias and Drake 1999; Drake et al. 1997), nor in previous faunistic checklists (Parapar et al. 2004). The association is regular (sensu Martin and Britayev 1998), with only one symbiont per host in all cases except for a single one in which one male and one female were found living inside the same host clam.

Currently, there are 11 known commensal hesionid species (Table 1), representing about $2.9 \%$ of the known commensal polychaetes (and around $7.5 \%$ of the known hesionid species). Commensalism in hesionids seems to be restricted to the clade Ophiodrominae, which also includes Parasyllidea, but certainly is a feature with multiple origins within hesionids. In fact, Ophiodromus and Gyptis, two of the most representative Ophiodrominae genera including commensal species (Table 1), are not closely related (Ruta et al. 2007). Moreover, both are species-rich genera, and we today have no evidence on whether commensalism within each of them has arisen once or several times.

Commensal hesionids are involved in about 36 different types of associations. Except for the polyxenous species of Ophiodromus (i.e., O. obscurus, O. flexuosus, and O. pugettensis), which are associated with many different hosts (i.e., 3, 10, and 12, respectively), most symbiotic hesionids are monoxenous, occurring in only one (6 species) or two ( 2 species) hosts. The most common hosts are echinoderms (particularly starfishes), followed by other Polychaeta (Table 1). A peculiar case is that of Anoplonereis hermanni, a species described by Giard (1882) as associated to two species of Balanoglossus. According to Pleijel (1998), the original description agrees with Ophiodromus, a well-known genus including several commensal species, but it is poorly known and there is no type material. Thus, it must at present be considered a nomen dubium.

In addition to $P$. humesi there is only one more hesionid living in association with a bivalve, and this is Ophiodromus pugettensis, which seems to be able to detect at a certain distance the presence of at least two of its host starfishes, Patiria miniata and 
Luidia foliolata (Davenport et al. 1960). Also there are some indications of mutualistic behavior in their relationships, with one of its echinoid hosts, the sand dollar Clypeaster humilis (Storch and Niggemann 1967). During sample handling, all isolated specimens of $P$. humesi that were maintained in small aquaria containing specimens of S. plana were always found in close contact with them, either below or crawling on the shell. Although this seems to indicate that the symbiont may be attracted by its host from a certain distance, further studies are required to experimentally demonstrate either the presence of a host-factor (similar to that in the association between O. pugettensis and its host starfish) or the apparent specificity of its association with S. plana (e.g., by allowing the worm to be in contact with other bivalves).

However, contrary to $O$. pugettensis, our results point to a negative effect of the presence of $P$. humesi inside $S$. plana, as the infested hosts showed a significantly reduced body mass compared to the non-infested ones (Fig. 5c). The fact that the presence of symbionts may affect the metabolism of their host bivalves, and thus their normal growth (Bierbaum and Ferson 1986), has been previously reported for other polychaete species living in the mantle chamber of bivalves, such as Branchipolynoe seepensis living inside Bathymodiolus spp. (Britayev et al. 2007). Accordingly, this could be considered as an indication that the association between $P$. humesi and $S$. plana is closer to parasitism than to commensalism or mutualism. However, contrary to B. seepensis, no damages in the tissues of S. plana have been observed in the Gulf of Cádiz population. Thus, further studies are again required to assess the exact nature of the association.

Acknowledgements The authors wish to thank the "Plan Andaluz de Investigación Desarrollo e Innovación" (PAIDI) of the "Junta de Andalucía" for funding the research group RNM108, the "Parque Natural Bahía de Cádiz" by sampling facilities, and the "Generalitat de Catalunya" for its support to the Consolidated Research Group 2009SRG665. This manuscript is a contribution to the research project BENTHOMICS (ref. no. CTM2010-22218-C02-01) financed by the Spanish Commission of Science and Technology (CICYT).

\section{References}


Anker, A., Murina, G. V., Lira, C., Vera Caripe, J. A., Palmer, A. R., \& Jeng, M. S. (2005). Macrofauna associated with echiuran burrows: A review with new observations of the innkeeper worm, Ochetostoma erythrogrammon Leuckart and Rüppel, in Venezuela. Zoological Studies, 44(2), 157-190.

Ardovini, R., \& Cossignani, T. (2004). West African seashells (including Azores, Madeira and Canary Is.). Ancona: L'Informatore Piceno.

Arias, A. M., \& Drake, P. (1999). Fauna acuática de las salinas del Parque Natural Bahía de Cádiz. Sevilla: Consejería de Medio Ambiente de la Junta de Andalucía.

Barel, C. D. N., \& Kramers, P. G. N. (1977). A survey of the echinoderm associates of the North-East Atlantic area. Zoologische Verhandelingen. Leiden, 156, 1-159.

Bartel, A. H., \& Davenport, D. (1956). A technique for the investigation of chemical responses in aquatic animals. British Journal of Animal Behaviour, 4, 117-119.

Bierbaum, R. M., \& Ferson, S. S. (1986). Do symbiotic pea crabs decrease growth rate in mussels? Biological Bulletin Marine Biological Laboratory, Woods Hole, 170, 5161.

Britayev, T. A., Martin, D., Krylova, E. M., von Cosel, R., \& Aksiuk, E. S. (2007). Life-history traits of the symbiotic scale-worm Branchipolynoe seepensis and its relationships with host mussels of the genus Bathymodiolus from hydrothermal vents Marine Ecology: An Evolutionary Perspective, 28(1), 36-48.

Bruguière, J. G. (1789). Encyclopédie Méthodique. Histoire Naturelle des Vers. Paris: Panckoucke.

Carvalho, S., Constantino, R., Cerqueira, M., Pereira, F., Subida, M. D., Drake, P., et al. (2011). Short-term impact of bait digging on intertidal macrobenthic assemblages of two south Iberian Atlantic systems. Estuarine, Coastal and Shelf Science, doi:10.1016/j.ecss.2011.06.017.

Claparède, É. (1864). Glanures zootomiques parmi les annélides de Port-Vendres (Pyrénées Orientales). Mémoires de la Société de Physique et d'Histoire Naturelle de Genève, 17(2ème partie), 463-600, pls. 461-468. 
Clark, R. B. (1956). Capitella capitata as a commensal, with a bibliography of parasitism and commensalism in the polychaetes. Annals and Magazine of Natural History, 12(2), 433-448.

Da Costa, E. M. (1778). Historia Naturalis Testaceorum Britanniae or The British Conchology; containing the description and other particulars of Natural History of the shells of Great Britain and Ireland. London, Millan: White, Elmsley \& Robson.

Davenport, D., Camougis, G., \& Hickok, J. F. (1960). Analysis of the behaviour of commensals in host-factor. I. A hesionid polychaete and pinnotherid crab. Animal Behaviour, 8, 209-218.

Davenport, D., \& Hickok, J. F. (1957). Notes on the early stages of the facultative commensal Podarke pugettensis (Polychaeta, Hesionidae). Annals and Magazine of Natural History, 10, 625-631.

Delle Chiaje, S. (1827). Memorie sulla storia e notomia degli animali senza vertebre del Regno di Napoli (Vol. 2). Napoli: Stamperia della Societá Tipografica.

Drake, P., Arias, A. M., \& Conradi, M. (1997). Aportación al conocimiento de la macrofauna supra y epibentónica de los caños mareales de la Bahía de Cádiz (España). Publicaciones Especiales del Instituto Español de Oceanografía, 23, 133141.

Drummond, A. J., Ashton, B., Buxton, S., Cheung, M., Cooper, A., Heled, J., et al. (2010). Geneious v5.1. Available from http://www.geneious.com/ (accessed 6 February 2011).

García-Lafuente, J., Delgado, J., Criado-Aldeanueva, F., Bruno, M., del Río, J., \& Vargas, J. M. (2006). Water mass circulation on the continental shelf of the Gulf of Cádiz. Deep Sea Research Part II: Topical Studies in Oceanography, 53, 1182-1197.

Gardiner, S. L. (1976). Errant Polychaete Annelids from North Carolina. The Journal of the Elisha Mitchell Scientific Society, 91(3), 77-220.

Giard, M. A. (1882). Sur un type synthétique d'Annélide (Anoplonereis herrmanni) commensal des Balanoglossus. Comptes Rendues hebdomadaires des séances de l'Academie des Sciences, Paris, 95, 389-391. 
Gofas, S. (2011). Tellina Linnaeus, 1758. Accessed through: World Register of Marine Species at http://www.marinespecies.org/aphia.php?p=taxdetails\&id=138533 on 2011-11-10.

Grube, A. E. (1878). Annulata Semperiana. Beiträge zur Kenntniss der Annelidenfauna der Philippinen. Mémoires de L'Academie Imperiale des Sciences de St. Petersbourg, série 7, 25(8), 1-300, pls. 319.

Hagen, E. (2001). Northwest African upwelling scenario. Oceanologica Acta, 24, Supplement 1(0), 113-128, doi:10.1016/s0399-1784(00)01110-5.

Hartman, O. (1951). The littoral marine Annelids of the Gulf of Mexico. Publications of the Institute of Marine Sciences, 2(1), 7-124.

Hartmann-Schröder, G. (1959). Zur Ökologie der Polychaeten des Mangrove-EsteroGebietes von El Salvador. Beiträge zur Neotropischen Fauna, 1(2), 69-183.

Hartmann-Schröder, G. (1980). Zur kenntnis des Eulitorals der australischen Küsten unter besonderer Berücksichigung des Polychaeten und Ostracoden. Teil 4. Die Polychaeten der tropischen Nordwestküste Australiens (zwischen Port Samson im Norden und Exmouth im Süden). Mitteilungen aus dem Hamburgischen zoologischen Museum und Institut, 78, 19-96.

Hickok, J. F., \& Davenport, D. (1957). Further studies in the behavior of commensal polychaetes. Biological Bulletin Marine Biological Laboratory, Woods Hole, 113, 397-406.

Hilbig, B. (1994). Volume 4 - The Annelida Part 1. 9. Family Hesionidae Sars, 1862. In J. A. Blake, \& B. Hilbig (Eds.), Taxonomic atlas of the benthic fauna of the Santa Barbara Basin and western Santa Barbara Channel (pp. 243-269). Santa Barbara: Santa Barbara Museum of Natural History.

Johnson, H. P. (1901). The Polychaeta of the Puget Sound region. Proceedings of the Boston Society for Natural History, 29(18), 381-437, pls. 319.

Jones, S. (1964). Notes on animal associations. 4. The starfish Pentaceros hedemanni (Lutken) and the hesionid polychaete Podarke angustifrons (Grube). Journal of the Marine Biological Association of India, 6, 249-250. 
Knox, G. A. (1960). The Polychaeta Errantia of the Chatham Islands 1954 expedition. New Zealand Department of Scientific and Industrial Research Bulletin, 139, 77-143.

Lamarck, J. B. d. (1818). Histoire naturelle des Animaux sans Vertèbres, préséntant les caractères généraux et particuliers de ces animaux, leur distribution, leurs classes, leurs familles, leurs genres, et la citation des principales espèces qui s'y rapportent; précédée d'une Introduction offrant la détermination des caractères essentiels de l'animal, sa distinction du végétal et des autres corps naturels, enfin, l'exposition des principes fondamentaux de la zoologie (Vol. 5). Paris: Déterville \& Verdière.

Lande, R., \& Reish, D. J. (1968). Seasonal occurrence of the commensal polychaetous annelid Ophriodromus pugettensis on the starfish Patiria miniata. Bulletin of the Southern California Academy of Sciences, 67, 104-111.

Linnaeus, C. (1767). Systema naturae per regna tria naturae, ecundum Classes, Ordines, Genera, Species, cum characteribus, differentiis, synonymis, locis (Editio Decima, reformata ed., Vol. 1). Stockholm: Laurentii Salvii.

Manning, R. B. (1993). West Africa pinnotherid crabs, subfamily Pinnotherinae (Crustacea, Decapoda, Brachyura). Bulletin du Museum National d'Histoire Naturelle Paris, Série 4, Section A, 15 (1-4)((1-4)), 125-177.

Martin, D., \& Britayev, T. A. (1998). Symbiotic polychaetes: Review of known species. Oceanography and Marine Biology: An Annual Review, 36, 217-340.

Miller, W., \& Wolf, M. (2008). Crawling with worms: A look at two symbiotic relationships between polychaetes and urchins from the Bahamas. University of Oregon Scholars' Bank (pp. 1-10. https://scholarsbank.uoregon.edu/dspace/handle/ 1794/6875). Oregon: University of Oregon.

Nicklès, M. (1950). Mollusques testacés marins de la Côte occidentale d'Afrique (Vol. II, Manuels ouest-africains). Paris: Paul Lechevalier.

Okuda, S. (1936). Description of two polychaetous annelids found in burrows of an apodous holothurian. Annotations on Zoology, Japan, 15, 410-415. 
Palumbi, S. R. (1996). Nucleic acids II: the polymerase chain reaction. In D. M. Hillis, C. Moritz, \& B. K. Mable (Eds.), Molecular Systematics, second edition (pp. 205247). Sinauer: Massachusetts.

Pettibone, M. H. (1956). Some polychaete worms of the families Hesionidae, Syllidae, and Nereidae from the coast of North America, West Indies, and Gulf of Mexico. Journal of the Washington Academy of Sciences, 46(9), 281-294.

Pettibone, M. H. (1961). New species of polychaete worms from the Atlantic ocean, with a revision of the Dorvilleidae. Proceedings of the Biological Society of Washington, 74(19), 167-186.

Pettibone, M. H. (1963). Marine polychaete worms of the New England region. Part 1. Families Aphroditidae through Trochochaetidae. Bulletin of the United States National Museum, 227, 1-356.

Pleijel, F. (1998). Phylogeny and classification of Hesionidae (Polychaeta). Zoologica Scripta, 27(2), 89-163, doi:10.1111/j.1463-6409.1998.tb00433.x.

Pleijel, F., Jondelius, U., Norlinder, E., Nygren, A., Oxelman, B., Schander, C., et al. (2008). Phylogenies without roots? A plea for the use of vouchers in molecular phylogenetic studies. Molecular Phylogenetics and Evolution, 48(1), 369.

Ricketts, E. F., Calvin, J., Hedgpeth, J. W., \& Phillips, D. W. (1985). Between Pacific tides. Stanford: Stanford University Press.

Ruta, C., Nygren, A., Rousset, V., Sundberg, P., Tillier, A., Wiklund, H., et al. (2007). Phylogeny of Hesionidae (Aciculata, Polychaeta), assessed from morphology, 18S rDNA, 28S rDNA, 16S rDNA and COI. Zoologica Scripta, 36(1), 99-107.

Steinbeck, J., \& Ricketts, E. F. (1941). Sea of Cortez. A leisurely journal of travel and research. With a scientific appendix comprising materials for a source book on the marine animals of the Panamic faunal province. New York: Viking Press.

Stewart, W. C. (1970). A study of the nature of the attractant emitted by the asteroid host of the commensal polychaete Ophiodromus pugettiensis. University of California, Santa Barbara. 
Storch, V., \& Niggemann, R. (1967). Auf Echinodermen lebende Polychaeten. Kieler Meeresforschungen, 23, 156-164.

Storch, V., \& Rosito, R. M. (1981). Polychaetes from interespecific associations found off Cebu. The Philippine Scientist, 18, 1-9.

Subida, M. D., Arias, A. M., Drake, P., García Raso, E., Rodríguez, A., \& Cuesta, J. A. (2011). On the occurrence of Afropinnotheres monodi Manning, 1993 (Decapoda: Pinnotheridae) in European waters. Journal of Crustacean Biology, 31(2), 367-369.

Verrill, A. E. (1874). Report upon the invertebrate animals of Vineyard Sound and the adjacent waters, with an account of the physical characters of the region. Report of the United States Commission for Fisheries, 1871-72, 295-778.

Parapar, J., Besteiro, C., Moreira, J. (2004). Familia Hesionidade Grube, 1850. In Viéitez, J. M., Alós, C., Parapar, J., Besteiro, C., Moreira, J., Núñez, J., et al. Annelida Polychaeta I. In M. A. Ramos, J. Alba, X. Bellés, J. Gosálbez, A. Guerra, E. Macpherson, et al. (Eds.), Fauna Iberica, 25, 210-267. Madrid: CSIC.

Webster, H. E. (1879). The Annelida Chaetopoda of the Virginian coast. Transactions of the Albany Institute, New York, 9, 202-272.

Webster, H. E., \& Benedict, J. E. (1887). The Annelida Chaetopoda, from Eastport, Maine. Annual Report of the United States Commission of Fish and Fisheries, Whashington 1885, 707-758.

Werle, E., Renner, M., Völker, M., \& Fiehn, W. (1994). Convenient single-step, one tube purification of PCR products for direct sequencing. Nucleic Acids Research, 22, 4354-4355. 


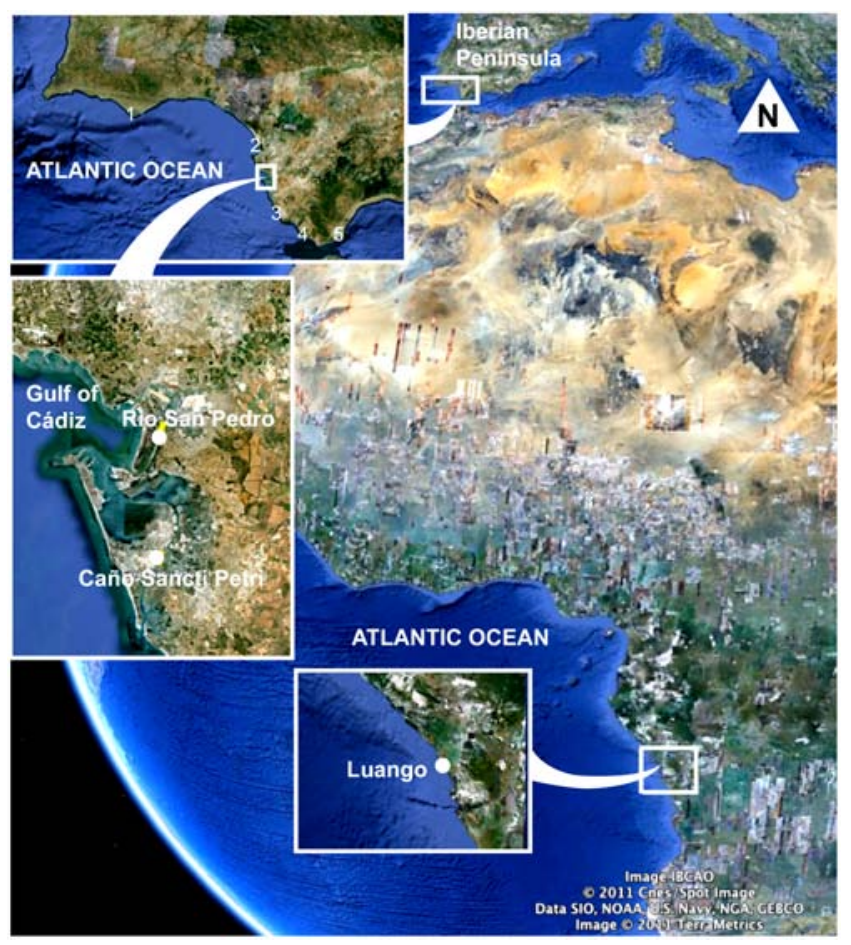

Fig. 1 Parasyllidea humesi Pettibone, 1961.

Geographic location of the two known populations in the Republic of Congo and in the Gulf of Cádiz (Caño Sancti Petri and Río San Pedro) and location of the remaining studied estuaries: (1) Ria Formosa; (2) Guadalquivir; (3) Salado; (4) Barbate; (5) Palmones.

Fig. 2 Scrobicularia plana (Da Costa, 1778). a Measurements taken on shells: length(1), width (w) and height (h). Parasyllidea humesi Pettibone, 1961. b Whole body, dorsal view. c Detail of anterior end, dorsal view. Scale bar: 3 $\mathrm{mm}, \mathbf{b}$ and $1 \mathrm{~mm}$, c.

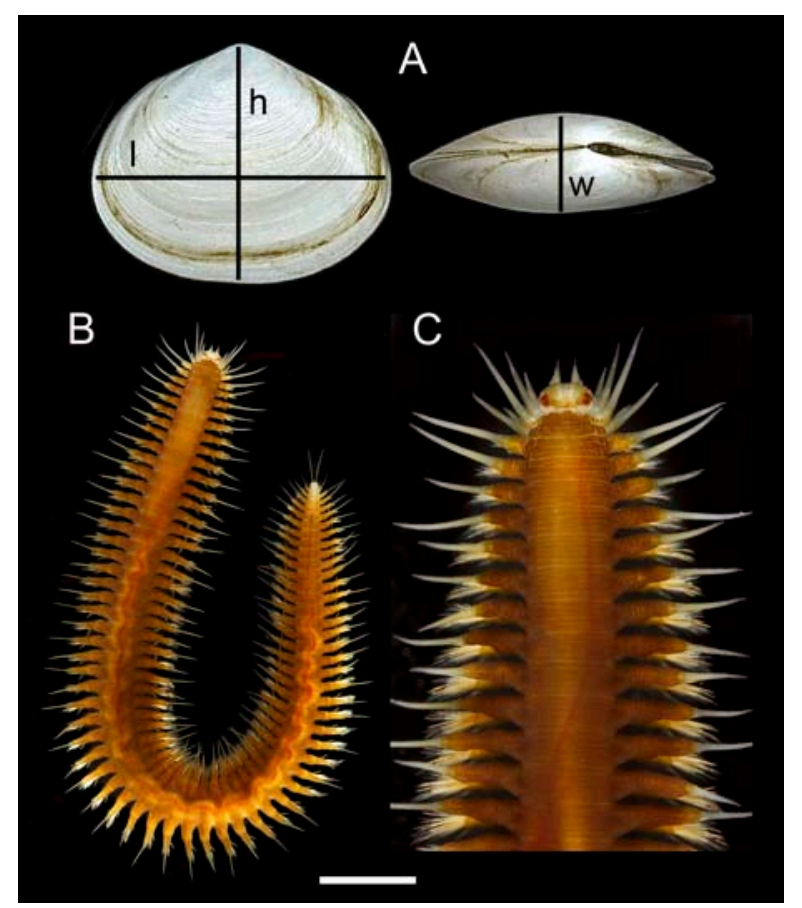




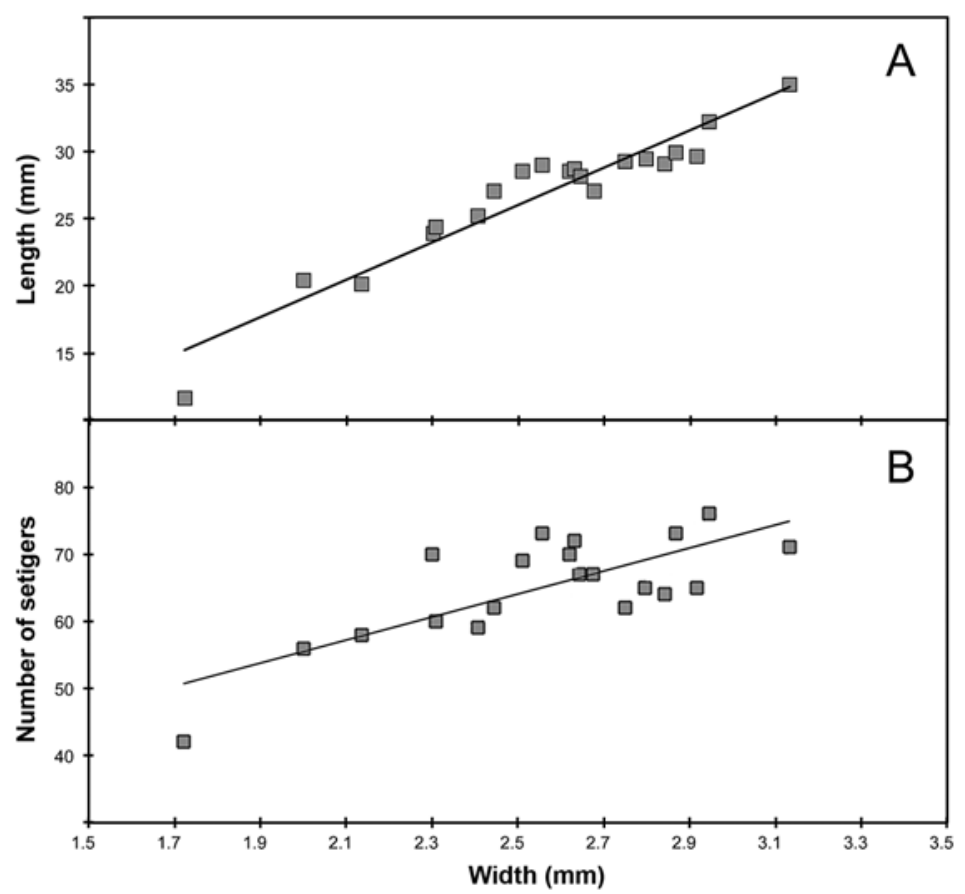

Fig. 3 Parasyllidea humesi Pettibone, 1961. Relationships between width and length. a Length in $\mathrm{mm}$. b Length as number of setigers.

Fig. 4 Scrobicularia plana (Da Costa, 1778). a Percentages of infested and non-infested specimens according to the size classes (shell length in $\mathrm{mm})(\mathrm{n}=2,373)$. b Relationships between length of infested shells and length of Parasyllidea humesi.
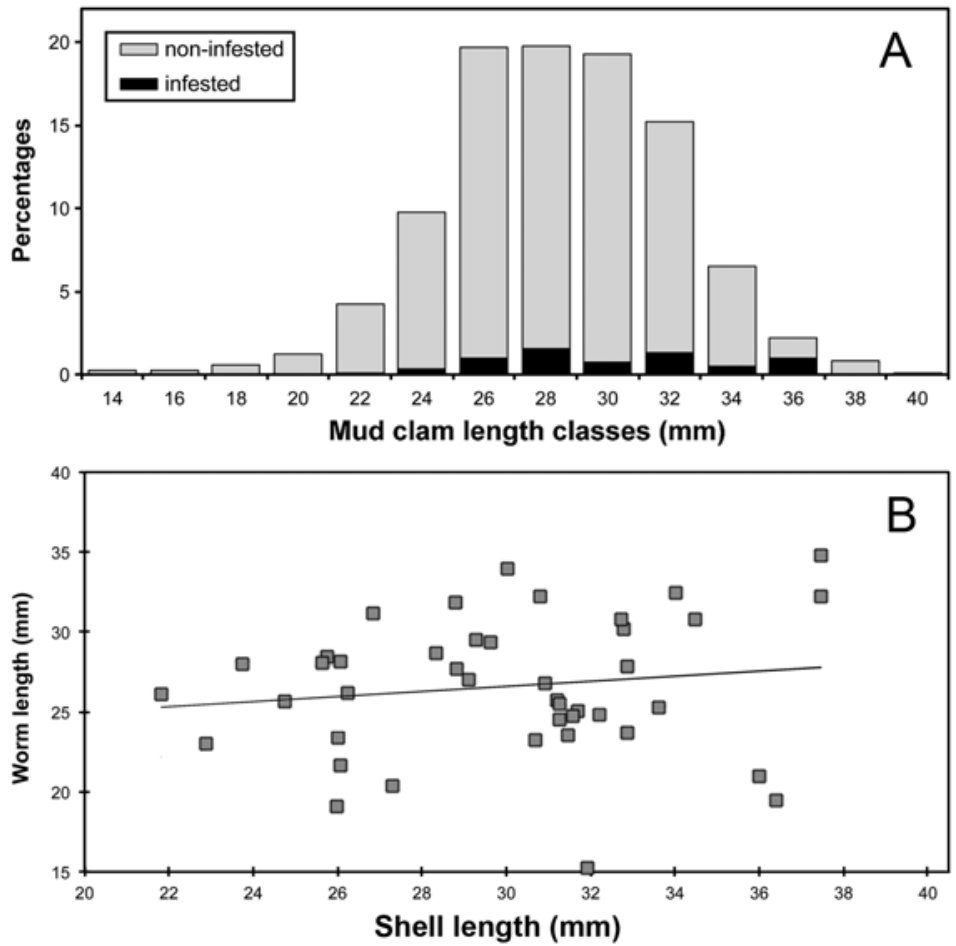


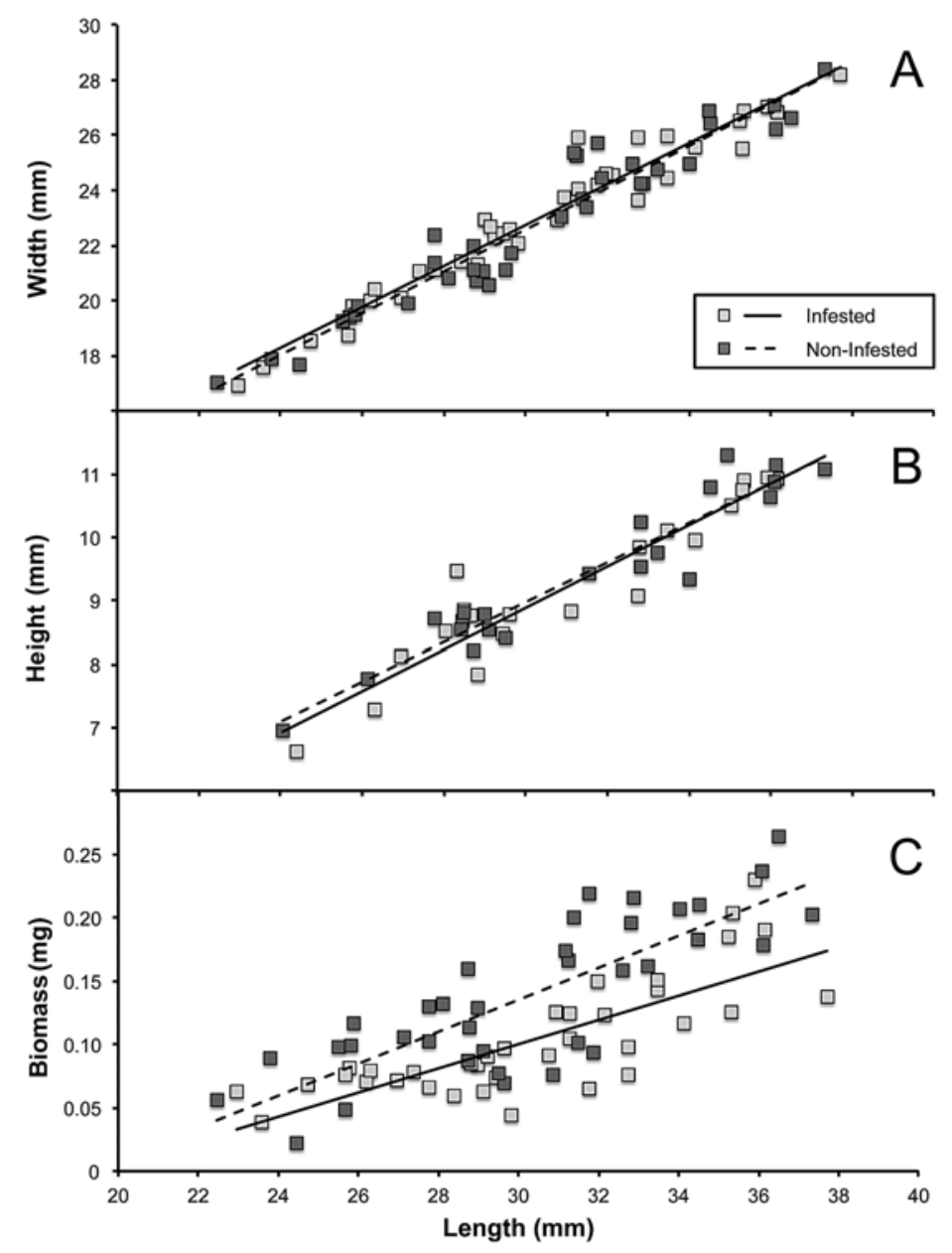

Fig. 5 Scrobicularia plana (Da Costa, 1778). Relationships of length vs. width (a), height (b), and biomass (c) in infested and non-infested specimens. 
Table 1. List of known symbiotic species of Hesionidae, updated from Martin and Britayev (1998).

\begin{tabular}{|c|c|c|c|c|}
\hline \multirow[t]{2}{*}{ SPECIES } & \multirow[t]{2}{*}{ AUTHORITY } & \multicolumn{2}{|c|}{ HOST } & \multirow[t]{2}{*}{ SOURCE } \\
\hline & & Group & Species & \\
\hline $\begin{array}{l}\text { Anoplonereis } \\
\text { herrmanni }\end{array}$ & Giard, 1882 & $\begin{array}{c}\text { Entereopneus } \\
\mathrm{t} \\
\text { Entereopneus } \\
\mathrm{t}\end{array}$ & $\begin{array}{l}\text { Balanoglossus } \\
\text { robinii. } \\
\text { Balanoglossus } \\
\text { salmonetus }\end{array}$ & $\begin{array}{l}\text { (Giard 1882) } \\
\text { (Giard 1882) }\end{array}$ \\
\hline Gyptis ophiocomae & $\begin{array}{l}\text { Storch \& } \\
\text { Niggemann, } \\
1967\end{array}$ & Ophiuroid & $\begin{array}{l}\text { Ophiocoma } \\
\text { scolopendrina }\end{array}$ & $\begin{array}{l}\text { (Storch and Niggemann } \\
\text { 1967) }\end{array}$ \\
\hline Gyptis vittata & $\begin{array}{l}\text { Webster \& } \\
\text { Benedict, } 1887\end{array}$ & Polychaete & $\begin{array}{l}\text { Notomastus } \\
\text { lobatus }\end{array}$ & (Gardiner 1976) \\
\hline \multirow[t]{2}{*}{$\begin{array}{l}\text { Podarkeopsis } \\
\text { brevipalpus }\end{array}$} & $\begin{array}{l}\text { (Hartmann- } \\
\text { Schröder, 1959) }\end{array}$ & Polychaete & Glycera robusta & (Gardiner 1976) \\
\hline & & Holothuroid & $\begin{array}{l}\text { Leptosynapta } \\
\text { tenuis }\end{array}$ & (Gardiner 1976) \\
\hline Parahesione luteola & (Webster, 1879) & Decapod & Upogebia affinis & (Pettibone 1956) \\
\hline \multirow[t]{2}{*}{ Parasyllidea humesi } & Pettibone, 1961 & Bivalve & Tellina nymphalis & (Pettibone 1961) \\
\hline & & Bivalve & $\begin{array}{l}\text { Scrobicularia } \\
\text { plana }\end{array}$ & This paper \\
\hline \multirow{11}{*}{$\begin{array}{l}\text { Ophiodromus } \\
\text { angustifrons } \\
\text { Ophiodromus } \\
\text { flexuosus }\end{array}$} & (Grube, 1878) & Asteroid & $\begin{array}{l}\text { Pentaceros } \\
\text { hedemanni }\end{array}$ & (Jones 1964) \\
\hline & $\begin{array}{l}\text { (Delle Chiaje, } \\
1827 \text { ) }\end{array}$ & Asteroid & $\begin{array}{l}\text { Astropecten } \\
\text { aranciacus }\end{array}$ & (Barel and Kramers 1977) \\
\hline & & Asteroid & $\begin{array}{l}\text { Astropecten } \\
\text { bispinosus }\end{array}$ & (Barel and Kramers 1977) \\
\hline & & Asteroid & $\begin{array}{l}\text { Astropecten } \\
\text { platyacanthus }\end{array}$ & (Barel and Kramers 1977) \\
\hline & & Asteroid & $\begin{array}{l}\text { Astropecten } \\
\text { irregularis }\end{array}$ & (Barel and Kramers 1977) \\
\hline & & Asteroid & Luidia ciliaris & (Barel and Kramers 1977) \\
\hline & & $\begin{array}{l}\text { Hemichordat } \\
\text { a }\end{array}$ & Balanoglossus sp. & (Clark 1956) \\
\hline & & Echiuroid & $\begin{array}{l}\text { Maxmuelleria } \\
\text { lankesteri }\end{array}$ & (Anker et al. 2005) \\
\hline & & Holothuroid & Leptosynapta sp. & (Barel and Kramers 1977) \\
\hline & & Polychaete & $\begin{array}{l}\text { Amphitrite } \\
\text { edwardsi }\end{array}$ & (Barel and Kramers 1977) \\
\hline & & Polychaete & $\begin{array}{l}\text { Euclymene } \\
\text { lumbricoides }\end{array}$ & (Barel and Kramers 1977) \\
\hline \multirow{3}{*}{$\begin{array}{l}\text { Ophiodromus } \\
\text { obscurus }\end{array}$} & (Verrill, 1874) & Polychaete & Lysilla alba & (Pettibone 1963) \\
\hline & & Echinoid & Lytechinus sp. & (Hartman 1951) \\
\hline & & Holothuroid & Thyone sp. & (Pettibone 1963) \\
\hline \multirow{2}{*}{$\begin{array}{l}\text { Ophiodromus } \\
\text { pallidus } \\
\text { Ophiodromus } \\
\text { pugettensis }\end{array}$} & $\begin{array}{l}\text { (Claparède, } \\
\text { 1864) }\end{array}$ & Echiuroid & Lissomyema exilii & (Anker et al. 2005) \\
\hline & (Johnson, 1901) & Asteroid & Luidia foliolata & $\begin{array}{l}\text { (Bartel and Davenport } \\
\text { 1956; Davenport et al. } \\
\text { 1960; Lande and Reish } \\
\text { 1968; Ricketts et al. 1985) } \\
\text { (Davenport et al. 1960; } \\
\text { Stewart 1970; Hilbig } \\
\text { 1994) }\end{array}$ \\
\hline
\end{tabular}




\begin{tabular}{|c|c|c|c|}
\hline & Asteroid & Luidia magnifica & (Storch and Rosito 1981) \\
\hline & Asteroid & $\begin{array}{l}\text { Pteraster } \\
\text { tesselatus }\end{array}$ & $\begin{array}{l}\text { (Storch and Niggemann } \\
\text { 1967) }\end{array}$ \\
\hline & Asteroid & $\begin{array}{l}\text { Oreaster } \\
\text { occidentalis }\end{array}$ & $\begin{array}{l}\text { (Steinbeck and Ricketts } \\
\text { 1941) }\end{array}$ \\
\hline & Asteroid & Pisaster ochraceus & $\begin{array}{l}\text { (Davenport and Hickok } \\
\text { 1957; Hickok and } \\
\text { Davennort 1957) }\end{array}$ \\
\hline & Holothuroid & $\begin{array}{l}\text { Protankyra } \\
\text { bidentata }\end{array}$ & $\begin{array}{l}\text { Davenport 195/) } \\
\text { (Okuda 1936) }\end{array}$ \\
\hline & Decapod & Eupagurus sp. & $\begin{array}{l}\text { (Hickok and Davenport } \\
\text { 1957) }\end{array}$ \\
\hline & Gastropod & Aletes sp. & $\begin{array}{l}\text { (Storch and Niggemann } \\
\text { 1967) }\end{array}$ \\
\hline & Bivalve & Chama sp. & $\begin{array}{l}\text { (Storch and Niggemann } \\
\text { 1967) }\end{array}$ \\
\hline & Echinoid & Clypeaster humilis & $\begin{array}{l}\text { (Storch and Niggemann } \\
\text { 1967) }\end{array}$ \\
\hline Unidentified hesionid & Echinoid & $\begin{array}{l}\text { Linopneustes } \\
\text { longispinus }\end{array}$ & (Miller and Wolf 2008) \\
\hline
\end{tabular}

